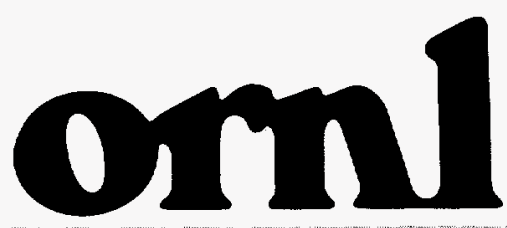

oAK RIDGE NATIONAL LABORATORY
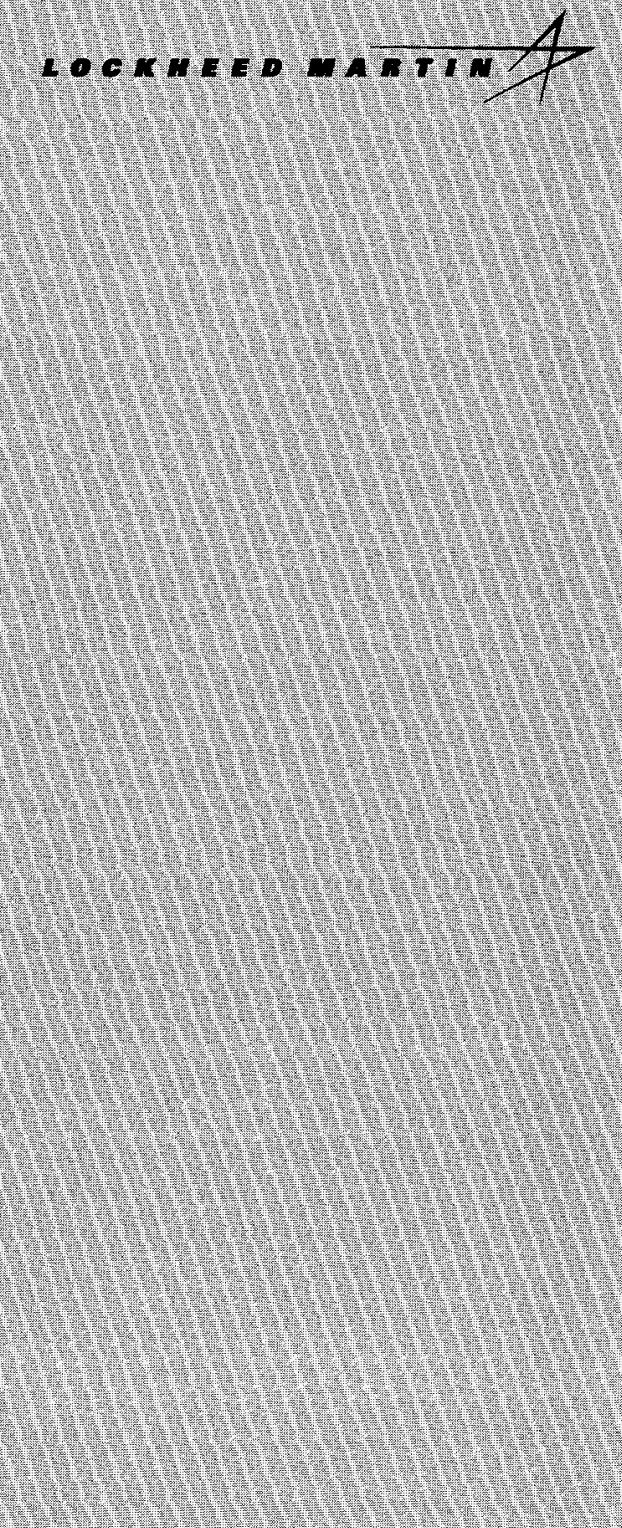

MANAGED AND OPERATED BY LOCKHEED MARTN ENERGY RESEARCH CORPORATION FOR THE UNTED STATES DEPARTUENT OF ENERGY

\title{
Source Term Evaluation During Seismic Events in the Paducah Gaseous Diffusion Plant
}

S. H. Kim

N. C. J. Chen

R. W. Schmidt

R. P. Taleyarkhan

\section{MASTER}

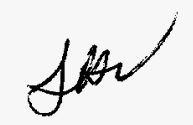

DISTRIBUTION OF THIS DOCUMENT IS UNLIMITED 
This report has been reproduced directly from the best available copy.

Available to DOE and DOE contractors from the Office of Scientific and Technical Information, P. O. Box 62, Oak Ridge, TN 37831; prices available from (423) 576-8401. FTS 626-8401.

Available to the public from the National Technical Information Service, U.S. Department of Commerce, 5285 Port Royal Road, Springfield. VA 22161.

This report was prepared as an account of work sponsored by an agency of the United States Government. Neither the United States Government nor any agency thereof, nor any of their employees. makes any warranty, express or implied, or assumes any legal liability or responsibility for the accuracy, completeness, or usefulness of any information, apparatus, product, or process disclosed, or represents that its use would not infringe privately owned rights. Reference herein to any specific commercial product, process, or service by trade name, trademark, manufacturer, or otherwise, does not necessarily constitute or imply its endorsement, recommendation, or favoring by the United States Government or any agency thereof. The views and opinions of authors expressed herein do not necessarily state or reflect those of the United States Government of any agency thereof. 


\section{DISCLAIMER}

Portions of this document may be illegible in electronic image products. Images are produced from the best available original document. 
ORNL/TM-13260

\title{
SOURCE TERM EVALUATION \\ DURING SEISMIC EVENTS \\ IN THE PADUCAH GASEOUS DIFFUSION PLANT
}

\author{
S.H. Kim \\ N.C.J. Chen \\ R.W. Schmidt \\ R.P. Taleyarkhan
}

December 30, 1996

\author{
Prepared by the \\ Oak Ridge National Laboratory \\ Oak Ridge, Tennessee 37831-8045 \\ managed by \\ LOCKHEED MARTIN ENERGY SYSTEMS, INC. \\ for the \\ U.S. DEPARTMENT OF ENERGY \\ under contract DOE-840R21400
}




\section{PAGE}

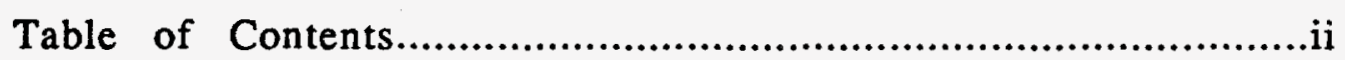

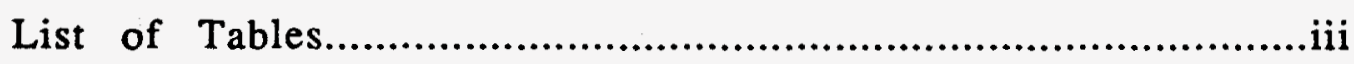

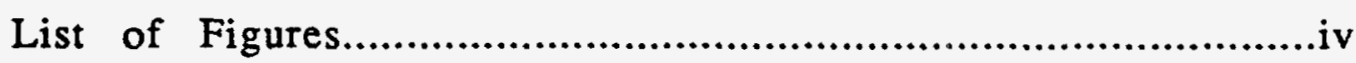

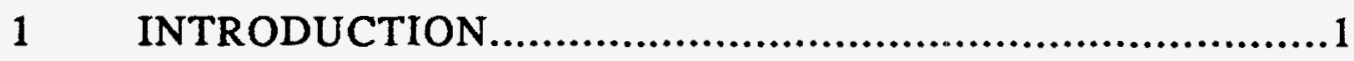

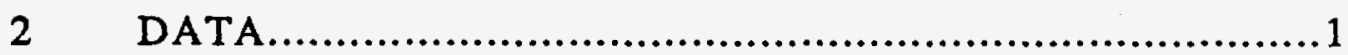

3 UF $_{6}$ RELEASE IMMEDIATELY AT THE BREAK........................4

3.1 Method of Approach................................................

3.2 Results and Discussion...........................................

$4 \quad$ UF $_{6}$ RELEASE FROM CONVERTERS.....................................

4.1 Converter Data....................................................9

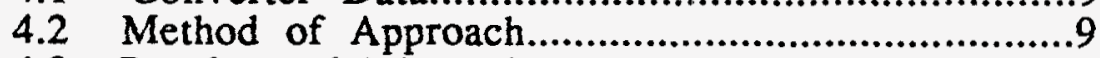

4.3 Results and Discussion...........................................13

5 SUMMARY AND CONCLUSIONS......................................14

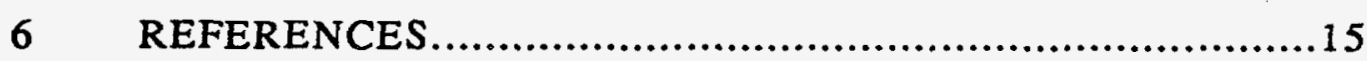




\section{LIST OF TABLES}

PAGE

Table $1 U F_{6-}$ Volume Expansion, Initial Release, and Pooled

Inventory in the Presence of Lubricant Oil Burning as A

Function of $U F_{6}$ Gas Temperature........................................................16

Table 2 Important Parameters Related to the Diffusion-Controlled

Process at the Interface Between $U F_{6}$ Gas and Air.. 


\section{LIST OF FIGURES}

\section{PAGE}

Figure 1 Temperature of R-114 $\mathrm{UO}_{2} F_{2}, \mathrm{HF}$ and air mixture as a function of $U F_{6}$ mass.

Figure 2 Temperature of R-114, $U O_{2} F_{2}, \mathrm{HF}$ and air mixture as a function of mass ration of $U F_{6}$ to R-114..............................17

Figure $3 \quad \mathrm{UO}_{2} F_{2}$ and $\mathrm{HF}$ mass variation for $2,200 \mathrm{MW}$ case.....................18

Figure $4 \quad \mathrm{UO}_{2} \mathrm{~F}_{2}$ and $\mathrm{HF}$ mass variation for 1,600 MW case.....................18

Figure $5 \quad \mathrm{UO}_{2} \mathrm{~F}_{2}$ and $\mathrm{HF}$ mass variation within a closed volume for 2,200 MW case.

Figure $6 \quad \mathrm{UO}_{2} \mathrm{~F}_{2}$ and $\mathrm{HF}$ mass variation within a closed volume for $1,600 \mathrm{MW}$ case.

Figure $7 \quad \mathrm{UO}_{2} \mathrm{~F}_{2}$ Mass Settled on Floor for 2,200 MW Case.....................20

Figure $8 \quad \mathrm{UO}_{2} \mathrm{~F}_{2}$ Mass Settled on Floor for 1,600 MW Case......................20

Figure $9 \quad U F_{6}$ and HF Release Period from Converters..............................21 


\section{Source Term Evaluation During Seismic Events in the Paducah Gaseous Diffusion Plant}

\section{INTRODUCTION}

The ' 00 ' buildings are expected to collapse (per guidance from structure evaluation) during a seismic event in which acceleration level exceeds $0.15 \mathrm{~g}$. All roof beams may slip off supports, and collapse. Equipment may slip off from supports and fall onto the floor. The cell floor is also supposed to collapse due to structural instability and distortion due to excessive acceleration forces. Following structure collapse, expansion joints in the process piping and joints between the piping and equipment are expected to fail. Preliminary analysis showed that converters are very likely to remain intact. The $\mathrm{UF}_{6}$ gas released from the break will rapidly interact with moisture in the air to produce $\mathrm{UO}_{2} \mathrm{~F}_{2}$ and $\mathrm{HF}$ with exothermic energy released of $\sim 0.32 \mathrm{MJ} / \mathrm{kg}$ of $\mathrm{UF}_{6}$ reacted. Depending on the degree of mixing between $\mathrm{UF}_{6}$ gas, its reaction products, air and freon (R-114), there may occur a strong buoyancy force to disperse $\mathrm{UO}_{2} \mathrm{~F}_{2}$ aerosol particles that are subjected to the gravitational force for settling. Such a chemical reaction will also occur inside the converters. A substantial amount of $\mathrm{UF}_{6}$ must be stagnated at the bottom of the converters. At the interface between this stagnated $\mathrm{UF}_{6}$ and air, $\mathrm{UF}_{6}$ gas will diffuse into the air, undergo the chemical reaction with moisture there, and eventually be released through the break. Furthermore, lubricant oil fire in the building, if it occurs, will enhance the UF 6 release into the atmosphere. The purpose of this study is to evaluate source term $\left(\mathrm{UO}_{2} \mathrm{~F}_{2}\right.$ and HF) during such a seismic event. This study takes an approach using multiple steps as follows:

(1) Source term evaluation at the break due to mixing between $\mathrm{UF}_{6}$ and air along with thermal buoyancy induced by chemical reaction energy,

(2) Evaluation of additional source term from the converters in which a substantial $\mathrm{UF}_{6}$ vapor remains, and

(3) Source term evaluation with lubricant oil fire

\section{DATA}

The amount of $\mathrm{UF}_{6}$ initial release into the air at the break is based on a few simple values: the total $\mathrm{UF}_{6}$ inventory in the ' 00 ' buildings minus the amount of $\mathrm{UF}_{6}$ that can be stagnant in the bottom of the on-stream ' 00 ' converters. From other work we believe that the 
converters and process piping will remain largely intact (no crushing) after the building collapse, but the expansion joints and other piping/equipment connections will fail. The motors and compressors are also expected to stop very rapidly once the building begins to . collapse. Since $\mathrm{UF}_{6}$ gas is much denser than air, it will tend to flow to the lowest point in the system. In most of the piping and related equipment, we cannot reasonably expect the $\mathrm{UF}_{6}$ gas to remain inside the process equipment, as breaks may occur at or very near the lowest points. However, the converters have a significant volume below the level of the $\mathrm{UF}_{6}$ inlet and outlets. $\mathrm{UF}_{6}$ gas is therefore expected to be stagnant in the bottom of the converters.

The total inventory in the ' 00 ' process buildings is easily calculated from the building power level. The volume available for pooling is the number of on-stream converters times the pool volume in each converter. The total volume available for stagnation times the density of $\mathrm{UF}_{6}$ gas at process temperatures and atmospheric pressure gives the amount of inventory stagnated in the bottom of the converters. The remaining inventory is assumed to be released into the building immediately when the building collapsed. The $\mathrm{UF}_{6}$ in the converters will react much more slowly, and any release will be limited by the barrier in the converter shell.

\section{Basic '00' Process Building Information}

- '00' process building volume, after collapse $=640 \mathrm{ft} \times 804 \mathrm{ft} \times \sim 10 \mathrm{ft}(195.1 \mathrm{~m} \times 804$ $\mathrm{m} \mathrm{x} \sim 3 \mathrm{~m})=5 \times 10^{6} \mathrm{ft}^{3}\left(1.42 \times 10^{5} \mathrm{~m}^{3}\right)$

(the volume occupied by the process is not excluded because the process is open to the atmosphere)

- Each ' 00 ' process building cross section area $=640 \mathrm{ft} \times 804 \mathrm{ft}(195.1 \mathrm{~m} \times 804 \mathrm{~m})=$ $514,560 \mathrm{ft}^{2}\left(47,804 \mathrm{~m}^{2}\right)$

- Average process gas temperature $=260^{\circ} \mathrm{F}(400 \mathrm{~K})$ (from Steve Chambers gradient for $2200 \mathrm{MW}$ )

- Conversion factor for $\mathrm{MW}$ to Inventory $=407.8 \mathrm{lb}(185 \mathrm{~kg}) \mathrm{UF}_{\sigma} / \mathrm{MW}$ for ' $00^{\prime}$ equipment

- Total Cell Volume $=11,162 \mathrm{ft}^{3}\left(316.1 \mathrm{~m}^{3}\right)$

Combined Volume of the 10 converters $=8,060 \mathrm{ft}^{3}\left(228.2 \mathrm{~m}^{3}\right)$

Volume of piping, compressors, \& etc $=3,102 \mathrm{ft}^{3}\left(87.8 \mathrm{~m}^{3}\right)$ 
- Combined pool volume of the 10 converters $=1,818 \mathrm{ft}^{3}\left(51.5 \mathrm{~m}^{3}\right)$

Density of $\mathrm{UF}_{6}$ gas at $260^{\circ} \mathrm{F}(400 \mathrm{~K})$ and $1 \mathrm{~atm}=0.6 \mathrm{lb} / \mathrm{ft}^{3}\left(9.6 \mathrm{~kg} / \mathrm{m}^{3}\right)$

Specific heat capacity of $\mathrm{UF}_{6}$ gas at $260^{\circ} \mathrm{F}(400 \mathrm{~K})$ and $1 \mathrm{~atm}=0.089 \mathrm{BTU} / \mathrm{hb}-{ }^{\circ} \mathrm{F}$

$(0.3726 \mathrm{~kJ} / \mathrm{kg}-\mathrm{C})$

\section{$\underline{2200 \mathrm{MW} \text { Case }}$}

- Total '00' building inventory $=123,500 \mathrm{lb}$. $(56,019 \mathrm{~kg})$ of $U F_{6}$ per 80 cells

- Pooled Inventory remaining in converters $=59,589 \mathrm{lb}$. $(27,029 \mathrm{~kg})$ of $\mathrm{UF}_{6}(48 \%)$ per 80 cells

- Inventory released immediately to building $=63,911 \mathrm{lb}$. $(28,990 \mathrm{~kg})$ of $\mathrm{UF}_{6}(52 \%)$ per 80 cells

\section{MW Case}

- Total ' 00 ' building inventory $=100,870 \mathrm{lb}$. $(45,754 \mathrm{~kg})$ of $\mathrm{UF}_{6}$ per 80 cells

- Pooled Inventory remaining in converters $=59,589 \mathrm{lb}$. $(27,029 \mathrm{~kg})$ of $\mathrm{UF}_{6}(59 \%)$ per 80 cells

- Inventory released immediately to building $=41,281 \mathrm{lb}$. $(18,725 \mathrm{~kg})$ of $\mathrm{UF}_{6}(41 \%)$ per 80 cells

Note that the pooled inventory remained the same in both cases; that is because the number of ' 00 ' cells on-stream did not change, and therefore the volume available for pooling remained unchanged.

\section{Releases from Tie-Lines to ' 000 ' Buildings}

The collapse of the two ' 00 ' process buildings at Paducah would of course break the tie lines connecting them to the other process buildings. The total contents of the tie lines is about $2000 \mathrm{lb}$. ( $907 \mathrm{~kg}$ ) of $\mathrm{UF}_{6}$. Because the tie lines and the process equipment they connect to are operating well below atmospheric pressure, little else would be released. At $2200 \mathrm{MW}$, the pressures in the tie lines are about $12 \mathrm{psia}(82.7 \mathrm{kPa})$ for the B stream and 2.5 psia $(17.2 \mathrm{kPa}$ ) for the A stream. When these pipes are opened to the atmosphere, air will rush in both the A- and B-lines, bringing the pressure up to 1 atmosphere. If the other process buildings continue to operate after the earthquake, the compressor at the outlet of the tie line will lose it's effectiveness because of the inrushing air. Axial compressors in the GDPs typically operate with a pressure ratio of about 5 when pumping pure $\mathrm{UF}_{6}$. Test loop 
experiments have shown that the same compressors can only support a pressure ratio of 1.2 when operated on light gasses such as air or HF. In addition, sudden changes in gas composition and/or inlet pressure can cause the compressors to surge, in which the pressure ratio is 1 and the flow is near zero. Surging compressors vibrate very severely, and quickly deblade, ending their pumping ability. Therefore, with the exception of $\mathrm{UF}_{6}$ in the tie-lines, no additional amount of $\mathrm{UF}_{6}$ is expected to be released from the tie-line failure.

\section{R-114 Coolant}

A typical '00' cell has a coolant (R-114) volume of $740 \mathrm{ft}^{3}\left(21 \mathrm{~m}^{3}\right)$. Liquid $\mathrm{R}-114$ fills about $260 \mathrm{ft}^{3}\left(7.4 \mathrm{~m}^{3}\right)$, while $\mathrm{R}-114$ vapor fills the remaining $480 \mathrm{ft}^{3}\left(13.6 \mathrm{~m}^{3}\right)$. At the power levels we are looking at in the seismic analysis, the coolant temperature is normally around $150^{\circ} \mathrm{F}(339 \mathrm{~K})$. Selected thermal properties of $\mathrm{R}-114$ at $150^{\circ} \mathrm{F}(339 \mathrm{~K})$ and saturated conditions are given below :

$$
\begin{aligned}
& \text { Liquid Vapor Pressure }=96.0544 \mathrm{psia}(662.3 \mathrm{kPa}) \\
& \text { Vapor Specific Volume }=0.335811 \mathrm{ft}^{3} / \mathrm{b}\left(0.021 \mathrm{~m}^{3} / \mathrm{kg}\right) \\
& \text { Vapor specific heat capacity }=0.194472 \mathrm{BTU} / \mathrm{b}-{ }^{0} \mathrm{~F}\left(0.8142 \mathrm{~kJ} / \mathrm{kg}-{ }^{0} \mathrm{C}\right) \\
& \text { Sat. Liquid Density }=82.3820 \cdot \mathrm{lb} / \mathrm{ft}^{3}\left(1,319.7 \mathrm{~kg} / \mathrm{m}^{3}\right) \\
& \text { Sat. Vapor Density }=2.97787 \mathrm{lb} / \mathrm{ft}^{3}\left(47.7 \mathrm{~kg} / \mathrm{m}^{3}\right)
\end{aligned}
$$

With density values given above, an R-114 inventory is determined as :

- Vapor: $480 \mathrm{ft}^{3}\left(13.6 \mathrm{~m}^{3}\right) \times 2.97787 \mathrm{lb} / \mathrm{ft}^{3}\left(47.7 \mathrm{~kg} / \mathrm{m}^{3}\right)=1,429.4 \mathrm{lb}$. $(648.4 \mathrm{~kg}) 6.3$ wt. \%

(UF ${ }_{6}$ mass $/ \mathrm{R}-114$ mass $=0.56$ for $2,200 \mathrm{MW}$ case $\& 0.36$ for $1,600 \mathrm{MW}$ case)

- Liquid: $260 \mathrm{ft}^{3}\left(7.4 \mathrm{~m}^{3}\right) \times 82.3820 \mathrm{lb} / \mathrm{ft}^{3}\left(1,319.7 \mathrm{~kg} / \mathrm{m}^{3}\right)=21,419.3 \mathrm{lb} .(9,715.6 \mathrm{~kg})$ 93.7 wt. \%

- Total R-114 Inventory, per ' 00 ' cell $=22,848.7 \mathrm{lb}$. $(10,364 \mathrm{~kg})$

\section{UF, RELEASE IMMEDIATELY AT THE BREAK}

It was assumed that $\mathrm{UF}_{6}$ gas is released into the building atmosphere immediately after the pipe breaks following the building collapse due to the seismic event. The released $\mathrm{UF}_{6}$ gas interacts with moisture in the air to form $\mathrm{UO}_{2} \mathrm{~F}_{2}$ and $\mathrm{HF}$ which disperse into the air. 


\subsection{Method of Approach}

The MELCOR code was used to evaluate $\mathrm{UO}_{2} \mathrm{~F}_{2}$ and $\mathrm{HF}$ dispersion into the air with following assumptions.

- $\mathrm{UF}_{6}$ vapor is assumed to be released quickly (for present study assumed to be over 10 seconds).

- $\mathrm{UF}_{6}$ vapor is assumed to undergo instantaneous reaction with moisture in the air.

- The size of mixing volume is assumed to stay constant.

- Thermal equilibrium is assumed in the mixing volume.

- R-114 liquid is assumed to be stratified at the bottom and not to be available to thermally interact with vapor mixture.

- Water from the fire protection system and reactor coolant system is not considered.

- Lubricant oil fire is absent.

- $\mathrm{UF}_{6}$, air and R-114 are assumed to be perfectly mixed. Therefore, its mixing volume is evaluated as :

for $2.200 \mathrm{MW}$ case,

(1) $\mathrm{UF}_{6}$ vapor volume

total inventory released, $m_{U F 6}=\frac{63,911 \mathrm{lbs}}{80 \mathrm{cells}}=363 \mathrm{~kg} / \mathrm{cell}$

$V_{U F 6}=\frac{m_{U F 6}}{P_{U F 6}}=\frac{363 \mathrm{~kg} / \mathrm{cell}}{9.6 \mathrm{~kg} / \mathrm{m}^{3}}=37.38 \mathrm{~m}^{3} / \mathrm{cell}$

(2) Air volume

- Air volume is evaluated to have enough moisture content to react all the $\mathrm{UF}_{6}$ mass assuming $60 \%$ of relative humidity.

At $1 \mathrm{~atm}$ and $300 \mathrm{~K}, \mathrm{p}=760 \mathrm{mmHg}, \rho_{\mathrm{air}}=1.183 \mathrm{~kg} / \mathrm{m}^{3}$, $\&$ saturated water vapor pressure, $e_{\mathrm{s}}=31.824 \mathrm{mmHg}$

The relation between mixing ratio and relative humidity is related as

$$
\frac{m_{a i r}}{m_{H 2 O}}=\left(\frac{M_{\text {air }}}{M_{H 2 O}}\right) \frac{p}{(R . H .) e_{s}}=\frac{28.96}{18} \frac{760}{(0.6)(31.824)}=64
$$

where $M_{\text {air }}=$ molecular weight of dry air ( $\left.28.96 \mathrm{~kg} / \mathrm{mole}\right)$

$$
M_{H 2 O}=\text { molecular weight of water vapor }(18 \mathrm{~kg} / \mathrm{mole})
$$




$$
R . H .=\text { relative humidity }(60 \%)
$$

$\mathrm{H}_{2} \mathrm{O}$ mass required to react with $363 \mathrm{~kg}$ of $\mathrm{UF}_{6}$ is determined to be $37.13 \mathrm{~kg}$.

Thus,

$$
V_{\text {air }}=\frac{m_{\text {air }}}{\rho_{\text {air }}}=\frac{64 m_{H 2 O}}{\rho_{\text {air }}}=\frac{(64)(37.13) \mathrm{kg}}{1.183 \mathrm{~kg} / \mathrm{m}^{3}}=2,008.45 \mathrm{~m}^{3}
$$

(3) $R-114$ vapor volume

$$
V_{R 114}=480 \mathrm{ft}^{3}=13.6 \mathrm{~m}^{3}
$$

Therefore, total mixing volume is $2,059.83 \mathrm{~m}^{3}$

for $1,600 \mathrm{MW}$ case, mixing volume is similarly calculated to be $1,333.06 \mathrm{~m}^{3}$.

- Mixing volume height is evaluated per cell basis assuming that the mixture is uniformly distributed. Since the floor area of one building is $640 \mathrm{ft} \times 804 \mathrm{ft}(195.1 \mathrm{~m} \times 245.1 \mathrm{~m})$ (per 40 cells), each cell area will be (195.1) (245.1) / (40 cells) $=1,195 \mathrm{~m}^{2}$. Therefore, mixing height is determined to be $1.724 \mathrm{~m}$ and $1.116 \mathrm{~m}$ for $2,200 \mathrm{MW}$ and $1,600 \mathrm{MW}$ cases, respectively.

- Since MELCOR does not recognize R-114, its volume is assumed to be occupied by the air. Consequently, MELCOR evaluated mixing temperature will be higher than the actual temperature. In order to supplement the MELCOR calculated mixing temperature, a steady state mixing temperature is externally evaluated (for estimating the plume temperature rise) as

$$
\bar{T}=\frac{\left(m c_{p} T\right)_{R 114}+\left(m c_{p} T\right)_{a i r}+m_{U F 6} \dot{H}_{R}}{\left(m c_{p}\right)_{R 114}+\left(m c_{p}\right)_{U O 2 F 2}+\left(m c_{p}\right)_{H F}+\left(m c_{p}\right)_{a i r}}
$$

where $\dot{H}_{R}$ is chemical reaction energy of $\mathrm{UF}_{6}$ with moisture.

In the MELCOR model, one mixture volume is assumed to be connected to a large control volume representing the environment. Aerosol particles are assumed to be a log-normal distribution between $0.4 \mu \mathrm{m}$ and $2.5 \mu \mathrm{m}$. 


\subsection{Results and Discussion}

The mixing temperature using Eq. (4) are shown in Figures 1 and 2. Figure 1 shows the temperature of $\mathrm{R}-114, \mathrm{UO}_{2} \mathrm{~F}_{2}, \mathrm{HF}$ and air mixture as a function of the $\mathrm{UF}_{6}$ mass for various magnitude of $\mathrm{R}-114$ mass mixed in the volume. The mixing temperature is shown again in Fig.2, as a function of mass ratio of $\mathrm{UF}_{6}$ to $\mathrm{R}-114$. As mentioned above, the mass ratio is 0.56 and 0.36 for $2,200 \mathrm{MW}$ and 1,600 MW, respectively. Corresponding mixing temperature can be obtained as $385 \mathrm{~K}$ and $372 \mathrm{~K}$ for $2,200 \mathrm{MW}$ and 1,600 MW, respectively. Since the air temperature was assumed to be $300 \mathrm{~K}$, these temperatures represent $85 \mathrm{~K}$ and $72 \mathrm{~K}$ of temperature increase.

The magnitude of $\mathrm{UO}_{2} \mathrm{~F}_{2}$ and $\mathrm{HF}$ mass dispersed into the atmosphere and their temporal variations for 2,200 MW and 1,600 MW cases are shown in Figures 3 and 4. Also shown in the same figures, are the variations of $\mathrm{UO}_{2} \mathrm{~F}_{2}$ aerosol and $\mathrm{HF}$ vapor mass in the mixing volume. As seen in the figure, the dispersion (or release) can be characterized as initial pop release followed by a reduced rate of dispersion over a long period of time. The amount of $\mathrm{UO}_{2} \mathrm{~F}_{2}$ dispersed from the mixture volume shown in Figures 3 and 4, represents $63 \%$ and $62 \%$ of total $\mathrm{UO}_{2} \mathrm{~F}_{2}$ mass for $2,200 \mathrm{MW}$ and $1,600 \mathrm{MW}$ case, respectively. A substantial amount of HF vapor mass is shown to remain in the mixture volume for a long period of time because of lack of enough buoyancy at later time to disperse it out. Since all the building structures are assumed to collapse, however, this undisturbed HF vapor may be dispersed because of atmospheric condition such as wind.

$\mathrm{UO}_{2} \mathrm{~F}_{2}$ aerosols and $\mathrm{HF}$ vapor will not be confined within the mixing volume, nor limited from volume expansion. As soon as they are generated, they will be exposed to the atmospheric condition for dispersion while they get settled due to the gravitational force. To obtain an indication of the importance of gravitational settling during the release, the MELCOR calculations were repeated with a single closed volume to observe the trend of gravitation settling (closed volume case versus open volume case that was mentioned above). Since no environmental volume is connected to the mixing volume, we expect to have $100 \%$ of $\mathrm{UO}_{2} \mathrm{~F}_{2}$ aerosols to settle down onto the floor eventually. These results are shown in Figures 5 and 6 for 2,200 MW and 1,600 MW case, respectively. As seen in the figures, about $61 \%$ (195 kg for 2,200 MW case and $126 \mathrm{~kg}$ for $1,600 \mathrm{MW}$ case) of $\mathrm{UO}_{2} \mathrm{~F}_{2}$ aerosols is predicted to settle down onto the floor for the first $200 \mathrm{~s}$ of period, and another $25 \%$ settles down for next $300 \mathrm{~s}$. The remaining $14 \%$ gets settled down eventually for a 
long period of time. Therefore, $\mathrm{UO}_{2} \mathrm{~F}_{2}$ mass settled on the floor can be somewhere between values predicted for open volume and for closed volume, as shown in Figures 7 and 8 . The settled mass can vary between two curves in the same figures, depending on atmospheric conditions.

However, if lubricant oil fire occurs in the building, it is assumed that all of $\mathrm{UO}_{2} \mathrm{~F}_{2}$ and $\mathrm{HF}$ are released into the environment immediately. This is because strong turbulence induced by flames must exist to prevent the stagnation of vapor or settlement of aerosol particles on the ground.

\section{UF, RELEASE FROM CONVERTERS}

An analysis has been performed to assess the $\mathrm{UF}_{6}$ release from a converter with ruptured nozzles with and without lubricating oil pool fires. During a seismic event, inlet and outlet piping of converters may break with the converter itself remaining intact. Since processing lines are operated under atmospheric pressure, little of $\mathrm{UF}_{6}$ gases would be released. When these pipes are opened to the atmosphere, air will rush in both the inlet and outlet nozzles, bringing the pressure up to 1 atmosphere. UF 6 gas should be stratified within the converter bottom, and overflow through the break. Consequently, the level of $\mathrm{UF}_{6}$ should be stabilized at the neck of nozzles. The amount of subsequent release is slow because the mass transfer rate of $\mathrm{UF}_{6}$ is determined by a diffusion-controlled process at the interface between the $\mathrm{UF}_{6}$ and the air above it. An exothermic chemical reaction takes place when the diffusing $\mathrm{UF}_{6}$ reacts with moisture in air to produce $\mathrm{UO}_{2} \mathrm{~F}_{2}$ aerosols and $\mathrm{HF}$ gas, releasing heat of reaction of about $0.32 \mathrm{MJ} / \mathrm{kg}$ of $\mathrm{UF}_{6}$ reacted. During the accident, only $\mathrm{HF}$ gas is allowed to release out of converters and $\mathrm{UO}_{2} \mathrm{~F}_{2}$ aerosols would be trapped within the converters because of their complicated internal structures. The diffusion/reaction process continues until the $\mathrm{UF}_{6}$ gas is depleted.

On the contrary, if the collapse of the buildings causes lubricant oil to burn, a rapid initial $\mathrm{UF}_{6}$ release would occur as a result of the volume expansion caused by hot flame temperatures. Depending on the degrees of flame temperatures, a significant release of $\mathrm{HF}$ can occur initially. After this rapid spill, the release rate will decrease to a much slower diffusion-controlled process. 
The objective is to determine the initial rapid HF gas release, the slow diffusion-controlled release, and the release period to depletion of $\mathrm{UF}_{6}$ gas.

\subsection{Converter Data}

The equipment type of interest consists of $400 \mathrm{~A}$-line cooled size 00 converters with the following physical characteristics: a length of 221 in $(5.61 \mathrm{~m})$, a straight diameter of 90 in $(2.286 \mathrm{~m})$, a bulge diameter of $105 \mathrm{in}(2.667 \mathrm{~m})$, an inlet nozzle diameter of $423 / 16$ in $(1.072 \mathrm{~m})$, an A-outlet nozzle diameter of 36 in $(0.914 \mathrm{~m})$, a B-outlet nozzle diameter of 24 in $(0.61 \mathrm{~m})$, and an internal volume of $806 \mathrm{ft}^{3}\left(22.82 \mathrm{~m}^{3}\right)$. At both 2200 and $1600 \mathrm{MW}$ operations, the pooled inventory remaining in converters is $59,589 \mathrm{lb}$. $(27,029 \mathrm{~kg})$ of $\mathrm{UF}_{6}$ with an average process gas temperature running at $260^{\circ} \mathrm{F}(400 \mathrm{~K})$.

\subsection{Method of Approach}

Since the case without oil burning is a special case, it is necessary only to describe the calculation procedure once. As mentioned, in the presence of lubricant oil burning, the physical process involves two phasses: a rapid initial $\mathrm{UF}_{6}$ release controlled by the flame temperature, followed by a diffusion-controlled slow process. To start calculations, a flame temperature is assigned. Once the oil burning was ignited, it is reasonable to assume the converter is in thermal equilibrium with the flame; specifically, the converter wall temperature, the bulk mixture temperature and the flame temperature are assumed to be the same. When the states of $\mathrm{UF}_{6}$ are known, the volume expansion can be computed. Based on converter geometry, the amount of $\mathrm{UF}_{6}$ being spilled can be estimated from the excess volume. Consequently, the amount of pooled $\mathrm{UF}_{6}$ gas within the converter can be determined.

After this rapid $\mathrm{UF}_{6}$ spill, the release rate decreases as the diffusion-controlled mass transfer mechanism takes over at the interface between the $\mathrm{UF}_{6}$ pool and the air above it. The rate of mass transfer depends on the mass diffusion in gases, mass transfer coefficients, concentration gradients, and the interface area. In the calculations, all HF gas generated is assumed to escape from nozzles without choking. So long as the process is pseudo steady-state, the time interval for HF depletion can be calculated from information of the pooled inventory and mass transfer rate. 
(A) Initial Rapid Release from a Converter

In this simplified approach, the release process was assumed to consist of two independent steps. Step one involved a volume expansion from an initial stage to a final stage while keeping the pressure and mass constant. Step two involved a release of $\mathrm{UF}_{6}$ gas corresponding to the amount of volume excess.

\section{Initial UF 6 conditions:}

For $\mathrm{UF}_{6}$ gas pooled inventory per converter,

$$
m_{U F 6}=\frac{m_{U F, \text { total }}}{\text { total number of converters }}=\frac{59,589 \mathrm{lb}}{400}=148.97 \mathrm{lb}(67.57 \mathrm{~kg})
$$

Pressure inside the converter is assumed to be equilibrated with the outside as atmospheric pressure, and initial process gas temperature $\left(T_{i}\right)$ is $260^{\circ} \mathrm{F}$. Density of $\mathrm{UF}_{6}$ gas at this thermal condition is to be $0.6 \mathrm{lb} / \mathrm{ft}^{3}\left(9.6 \mathrm{~kg} / \mathrm{m}^{3}\right)$. Based on mass inventory and density, the initial volume is calculated as

$$
V_{i}=\frac{m_{U F 6}}{\rho_{U F 6}}=\frac{148.97}{0.6}=248.29 \mathrm{ft}^{3}\left(7.03 \mathrm{~m}^{3}\right)
$$

\section{Final $\mathrm{UF}_{\alpha}$ conditions:}

Assuming that the $\mathrm{UF}_{6}$ is an ideal gas, then under the constant pressure process, the final volume is calculated by:

$$
\frac{V_{f}}{V_{i}}=\frac{T_{f}}{T_{i}}
$$

where $T_{f}$ is $\mathrm{UF}_{6}$ gas temperature after expansion due to temperature increase followed by lubricant oil fire. The amount of $\mathrm{UF}_{6}$ release (spill) due to volume expansion is given by: 


$$
m_{U F 6, \text { released }}=m_{U F 6}\left(1-\frac{T_{i}}{T_{f}}\right)
$$

and the pooled $\mathrm{UF}_{6}$ inside the converter is given by:

$$
m_{U F, \text { pooled }}=m_{U F 6}\left(\frac{T_{i}}{T_{f}}\right)
$$

From the stoichiometric relation, HF mass is related as

$$
m_{H F}=m_{U F 6}\left(\frac{4 M_{H F}}{M_{U F 6}}\right)
$$

where

$$
\begin{aligned}
& M_{H F}=20 \mathrm{lb} / \text { mole, molecular weight of } \mathrm{HF} \text { gas, } \\
& M_{U F 6}=352 \mathrm{lb} / \text { mole, molecular weight of } \mathrm{UF}_{6} \text { gas, } \\
& m_{H F}=\text { mass of } \mathrm{HF} \text { gas (lb), } \\
& m_{U F 6}=\text { mass of } \mathrm{UF}_{6} \text { gas (lb), } \\
& T_{i}=\text { initial gas temperature in Rankin, and } \\
& T_{f}=\text { final gas temperature in Rankin. }
\end{aligned}
$$

(B) Slow Diffusion -Controlled Process at the Interface

Gilliland (Ref. 1) suggested an empirical equation based on published experimental data to obtain the diffusion coefficient as a function of the molecular properties of the diffusing gases:

$$
D=0.0069 T^{3 / 2} \frac{\left(\frac{1}{M_{\text {air }}}+\frac{1}{M_{U F 6}}\right)^{1 / 2}}{p\left(V_{\text {air }}^{1 / 3}+V_{U F 6}^{1 / 3}\right)^{2}}
$$

where 


$$
\begin{aligned}
& D=\text { diffusivity, } \mathrm{ft}^{2} / \mathrm{hr}, \\
& M_{\text {air }}=28.95 \mathrm{lb} / \mathrm{mole} \text {, molecular weight of air, } \\
& p=\text { pressure, atm., } \\
& T=\text { temperature, Rankin, } \\
& V_{\text {air }}=29.9 \text {, atomic volume of air, and } \\
& V_{U F 6}=27.92+6 \times 8.7=80.12 \text {, atomic volume of } \mathrm{UF}_{6} \text { gas. }
\end{aligned}
$$

Equation (11) should be used only as an approximation where experimental data are not available. Note that $D \sim T^{3 / 2}$, whereas actually in experimental results $D \sim T^{2}$ is usually found. The diffusivity was used to calculate the Schmidt number to be defined latter.

No data on mass transfer exist for this process, but by analogy to heat and momentum transfer, the following empirical equations proposed by Chilton and Colburn (Ref. 1) in turbulent flow systems hold:

$$
j_{D}=h_{D} \frac{S c^{2 / 3}}{u}
$$

and

$$
j_{H}=j_{D}=\frac{0.037}{\operatorname{Re}_{L}^{0.2}}
$$

where

$$
\begin{aligned}
& h_{D}=\text { mass transfer coefficient, } \mathrm{ft} / \mathrm{s}, \\
& j_{D}=\text { Chilton-Colburn } \mathrm{j} \text { factor for the mass transfer, } \\
& j_{H}=\text { Chilton-Colburn } \mathrm{j} \text { factor for the heat transfer, } \\
& R e_{L}=\text { Reynolds number based on a flat plate length of } \mathrm{L} \mathrm{ft}, \\
& S c=V / D, \text { Schmidt number } \\
& u=\text { air velocity, } \mathrm{ft} / \mathrm{s}
\end{aligned}
$$

Assuming that the $\mathrm{UF}_{6}$ behaves as an ideal gas, its concentration at the interface can be calculated by 


$$
C_{o}=\frac{p M_{U F 6}}{R T_{f}}
$$

where

$$
\begin{aligned}
& C_{0}=\text { concentration }\left(\mathrm{lb} / \mathrm{ft}^{3}\right), \\
& R=\text { universal gas constant }=1544 \text {, if } p \text { in } \mathrm{lb}_{\mathrm{f}} / \mathrm{ft}^{2}, T \text { in Rankin, } M_{U F G} \text { in } \mathrm{lb} / \text { mole. }
\end{aligned}
$$

The mass transfer rate at the interface within the converter is given by

$$
\dot{m}_{U F 6}=A h_{D}\left(C_{o}-C_{\infty}\right)
$$

where

$$
\begin{aligned}
& A=\text { interface area }=\pi \mathrm{d}^{2} / 4=\pi(105 / 12)^{2} / 4=60.13 \mathrm{ft}^{2}\left(5.59 \mathrm{~m}^{2}\right), \\
& C_{0}=\text { concentration at the interface }\left(\mathrm{lb} / \mathrm{ft}^{3}\right), \\
& C_{\infty}=\text { concentration at infinity }\left(\mathrm{lb} / \mathrm{ft}^{3}\right) .
\end{aligned}
$$

In the calculations using Eq. (15), the concentration at the interface was calculated as a function of temperature but the concentration at infinity away from the interface was assumed to be negligible (i.e., $C_{\infty}=0$ ). In addition, Equations (12) and (13) were combined to calculate $h_{D}$, which was then used in Eq. (15) for computing mass transfer rate.

\subsection{Results and Discussion}

In the presence of lubricant oil burning, the initial $\mathrm{UF}_{6}$ gas release is a function of the flame temperature (see Table 1). At a flame temperature of $1,700^{\circ} \mathrm{F}(1,200 \mathrm{~K})$, the volume of $U_{6}$ gas is expanded by a factor of 3 . Since the initial $U_{6}$ level is assumed to be at the neck of the converter, any excess volume is released to the atmosphere through the breaks. As a result, two-thirds of $\mathrm{UF}_{6}$ is released while one-third is left inside the converter. Also, because pressure is kept constant at the atmospheric pressure during this process, the $\mathrm{UF}_{6}$ density is decreased by a factor of 3 . Hence the pooled inventory is one-third of the initial $\mathrm{UF}_{6}$ mass.

In the absence of lubricant oil burning, parameters related to the diffusion-controlled process at the interface are also functions of temperature as shown in Table 2 . Both 
kinematic viscosity and diffusivity increase with increasing temperature; however, the Schmidt number (defined as the ratio between the kinematic viscosity and the diffusivity) remains about the same. The Reynolds numbers were calculated using an assumed air velocity of about $3 \mathrm{ft} / \mathrm{s}(0.91 \mathrm{~m} / \mathrm{s})$ and a characteristic length of 105 in $(2.667 \mathrm{~m})$ (the longest diameter of the converter). Within the temperature range of interest, the flow was turbulent as indicated by the Reynolds numbers, leading to a more effective diffusion. The mass transfer rate is a product of mass transfer $\left(h_{D}\right)$ and the concentration at the interface $\left(C_{o}\right)$, which have compensating effects. Even though the mass transfer coefficient increases slightly with the increasing temperature, but the opposite is true for the concentration at the interface. As a result, the mass transfer rate at the interface decreases as the temperature rises. The release period to depletion (defined as the ratio between the pooled inventory and the mass transfer rate) did not differ too much for both the absence ( $9.14 \mathrm{~min})$ and presence $(6 \sim 7 \mathrm{~min})$ of lubricant oil burning. This is because when the pooled inventory is high at a low temperature, mass transfer becomes more effective.

The release period of residual $\mathrm{UF}_{6}$ is plotted in Figure 9 for several different values of air/ $\mathrm{UF}_{6}$ vapor velocity. Certainly, it shows that the release period varies as the vapor velocity changes. However, the period still remains in the same order of magnitude (e.g., $\sim 5$ to $10 \mathrm{~min}$ at $2,000 \mathrm{~K}$ )

\section{SUMMARY AND CONCLUSIONS}

The '00' buildings are expected to collapse during a seismic event in which acceleration level exceeds $0.15 \mathrm{~g}$. A simplistic approach was taken to evaluate source term magnitude followed by a process piping break during such an event. Any $\mathrm{UF}_{6}$ vapor mass is assumed to be released through the break immediately after the pipe break. This $\mathrm{UF}_{6}$ vapor mixes with air to form a cloud and chemically react with moisture in the air. A resulting product, $\mathrm{UO}_{2} \mathrm{~F}_{2}$, is subjected to settle down on the ground due to gravity, and to disperse through the air. The magnitude of $\mathrm{UO}_{2} \mathrm{~F}_{2}$ aerosols to be settled onto the ground was estimated to be between about $32 \%(100 \mathrm{~kg} / 317.6 \mathrm{~kg})$ and $95 \%(300 \mathrm{~kg} / 317.6 \mathrm{~kg})$ for a period of $1,000 \mathrm{~s}$, as seen in Figure 7 for 2,200 MW case. For 1,600 MW, Figure 8 shows that about $34 \%(70 \mathrm{~kg} / 204.8 \mathrm{~kg})$ to $93 \%(190 \mathrm{~kg} / 204.8 \mathrm{~kg})$ of $\mathrm{UO}_{2} \mathrm{~F}_{2}$ aerosols was predicted to be settled over about the same period. However, if a large fire occurs in the building (possibly induced by lubricant oil fire), aerosols are not possible to settle due to strong 
buoyancy caused by large flames, and thus all the masses must be released and mixed with air to disperse through the environment.

Substantial $\mathrm{UF}_{6}$ mass is expected to remain inside the converters at the pipe break. Its release is diffusion-controlled at the interface of this stagnating $U_{6} F_{6}$ vapor pool and the air above it. If the converter becomes hot due to lubricant oil fire, $\mathrm{UF}_{6}$ volume must increase, and about 60 to $80 \%$ of initial $\mathrm{UF}_{6}$ mass in the converter was estimated to be released through breaks at the inlet and outlet nozzles. Remaining $\mathrm{UF}_{6}$ is subjected to slow release controlled by mass diffusion. The study shows that a complete depletion (release) of such a residual $\mathrm{UF}_{6}$ occurs over about $10 \mathrm{~min}$ without lubricant oil fire, and about $6-7 \mathrm{~min}$ with the fire.

\section{REFERENCES}

1. Rohsenow,W.M., and Choi, H. Y., Heat, Mass, and Momentum Transfer, PrenticeHall, Inc., New Jersey, 1961. 
Table 1. UF, Volume Expansion, Initial Release, and Pooled Inventory in the Presence of Lubricant Oll Burning as A Function of $\mathrm{UF}_{\mathbf{6}}$ Gas Temperature.

\begin{tabular}{|c|c|c|c|c|c|c|}
\hline $\mathrm{T}\left({ }^{\circ} \mathrm{F}\right)$ & $T(K)$ & $\begin{array}{l}\text { Vol. Expansion } \\
V N_{i}\end{array}$ & $\begin{array}{l}\text { Initial UF } \\
\text { Release }(\%)\end{array}$ & $\begin{array}{c}\mathrm{fF}_{6} \text { left in converter } \\
(\%)\end{array}$ & $\begin{array}{l}\mathrm{UF}_{6} \text { left in } \\
\text { converter }(\mathrm{lb})\end{array}$ & $\begin{array}{c}\mathrm{UF}_{6} \text { left in } \\
\text { converter }(\mathrm{kg})\end{array}$ \\
\hline 260 & 400 & 1.00 & 0 & 100 & 148.97 & 67.67 \\
\hline 300 & 422 & 1.06 & 5 & 95 & 141.13 & 64.02 \\
\hline 500 & 533 & 1.33 & 25 & 75 & 111.73 & 50.68 \\
\hline 750 & 672 & 1.68 & 40 & 60 & 88.64 & 40.21 \\
\hline 1000 & 811 & 2.03 & 51 & 49 & 73.47 & 33.32 \\
\hline 1250 & 950 & 2.38 & 58 & 42 & 62.73 & 28.45 \\
\hline 1500 & 1089 & 2.72 & 63 & 37 & 54.72 & 24.82 \\
\hline 1700 & 1200 & 3.00 & 67 & 33 & 49.66 & 22.52 \\
\hline 1800 & 1255 & 3.14 & 68 & 32 & 47.46 & 21.53 \\
\hline 1900 & 1311 & 3.28 & 69 & 31 & 45.45 & 20.62 \\
\hline 2000 & 1366 & 3.42 & 71 & 29 & 43.60 & 19.78 \\
\hline 2500 & 1644 & 4.11 & 76 & 24 & 36.24 & 16.44 \\
\hline 3000 & 1922 & 4.81 & 79 & 21 & 31.00 & 14.06 \\
\hline
\end{tabular}

Table 2. Important Parameters Related to the Diffusion-Controlled Process at the Interface Between $\mathrm{UF}_{6}$ Gas and Alr".

\begin{tabular}{|c|c|c|c|c|c|c|c|c|c|c|c|}
\hline $\mathrm{T}(\mathrm{F})$ & $\mathrm{T}(\mathrm{K})$ & $\begin{array}{c}v \\
\left(10^{-4} \mathrm{ft}^{2} / \mathrm{s}\right)\end{array}$ & $\underset{\left(10^{-4} \mathrm{ft}^{2} / s\right)}{\mathrm{D})}$ & Sc & $\begin{array}{c}\operatorname{Re} \\
\left(10^{4}\right)\end{array}$ & $\begin{array}{c}\mathbf{j}_{\mathbf{D}} \\
\left(10^{-3}\right)\end{array}$ & $\underset{\left(10^{-3} \mathrm{ft} / \mathrm{s}\right)}{\mathrm{h}_{\mathrm{D}}}$ & $\begin{array}{c}C_{o} \\
\left(\mathrm{lb} / \mathrm{ft}^{3}\right)\end{array}$ & $\begin{array}{c}\dot{m}_{v f \cdot} \\
(\mathrm{lb} / \mathrm{s})\end{array}$ & $\begin{array}{c}\dot{m}_{u F_{*}} \\
(\mathrm{~kg} / \mathrm{s})\end{array}$ & $\begin{array}{l}\text { Release } \\
\text { period } \\
(\mathrm{min})\end{array}$ \\
\hline 260 & 400 & 2.81 & 1.30 & 2.16 & 9.35 & 3.75 & 6.74 & 0.6703 & 0.2716 & 0.1232 & 9.14 \\
\hline 300 & 422 & 3.08 & 1.41 & 2.18 & 8.53 & 3.82 & 6.82 & 0.6350 & 0.2603 & 0.1181 & 9.04 \\
\hline 500 & 533 & 4.54 & 2.00 & 2.27 & 5.78 & 4.13 & 7.18 & 0.5027 & 0.2170 & 0.0984 & 8.58 \\
\hline 750 & 672 & 6.66 & 2.84 & 2.35 & 3.94 & 4.46 & 7.57 & 0.3988 & 0.1815 & 0.0823 & 8.14 \\
\hline 1000 & 811 & 9.06 & 3.76 & 2.41 & 2.90 & 4.74 & 7.91 & 0.3305 & 0.1572 & 0.0713 & 7.79 \\
\hline 1250 & 950 & 11.7 & 4.77 & 2.46 & 2.24 & 4.99 & 8.22 & 0.2822 & 0.1394 & 0.0632 & 7.50 \\
\hline 1500 & 1089 & 14.6 & 5.85 & 2.50 & 1.80 & 5.22 & 8.50 & 0.2462 & 0.1258 & 0.0571 & 7.25 \\
\hline 1700 & 1200 & 17.1 & 6.77 & 2.52 & 1.54 & 5.38 & 8.71 & 0.2234 & 0.1170 & 0.0531 & 7.07 \\
\hline 1800 & 1255 & 18.3 & 7.24 & 2.53 & 1.43 & 5.46 & 8.81 & 0.2135 & 0.1132 & 0.0513 & 6.99 \\
\hline 1900 & 1311 & 19.6 & 7.73 & 2.54 & 1.34 & 5.53 & 8.92 & 0.2045 & 0.1096 & 0.0497 & 6.91 \\
\hline 2000 & 1366 & 20.9 & 8.22 & 2.55 & 1.25 & 5.61 & 9.02 & 0.1962 & 0.1064 & 0.0482 & 6.83 \\
\hline 2500 & 1644 & 27.8 & 10.9 & 2.56 & 0.94 & 5.93 & 9.51 & 0.1630 & 0.0932 & 0.0423 & 6.48 \\
\hline 3000 & 1922 & 34.9 & 13.7 & 2.55 & 0.75 & 6.21 & 9.99 & 0.1395 & 0.0838 & 0.0380 & 6.17 \\
\hline
\end{tabular}

$* 0.91 \mathrm{~m} / \mathrm{s}(3 \mathrm{ft} / \mathrm{s})$ of air velocity was assumed. 


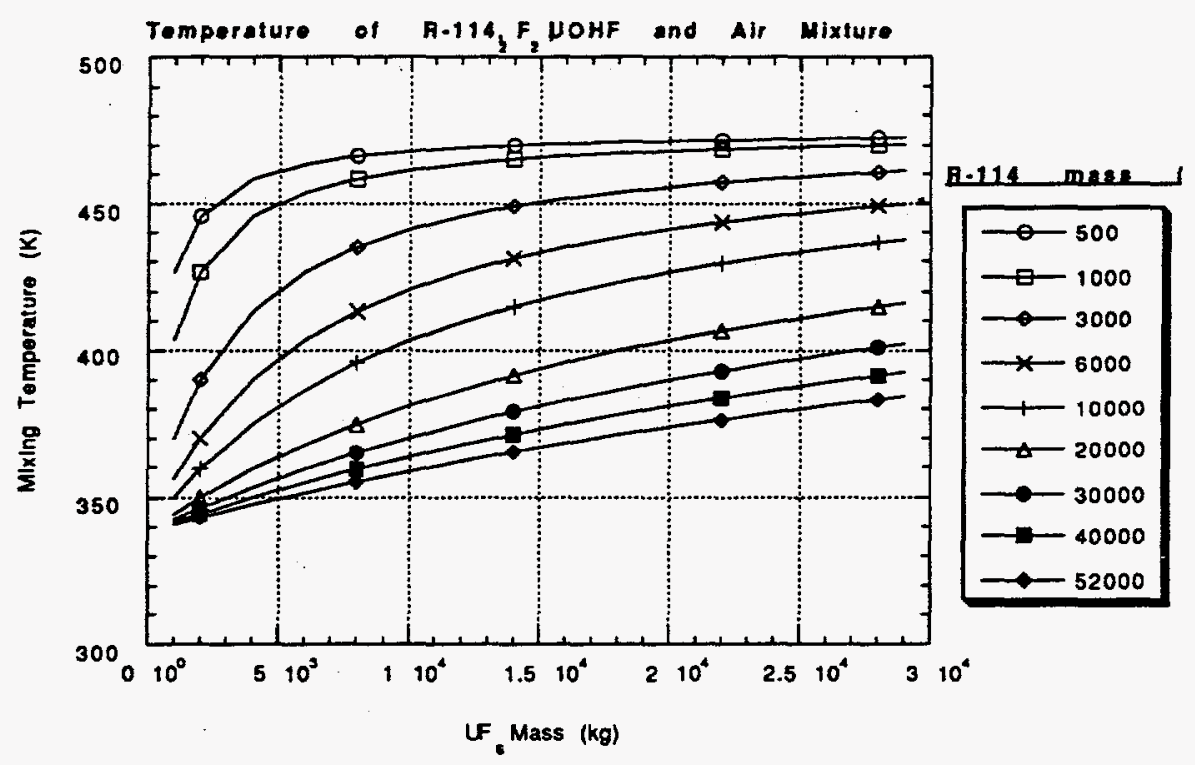

Figure 1 Temperature of $\mathrm{R}-114, \mathrm{UO}_{2} \mathrm{~F}_{2}, \mathrm{HF}$ and air mixture as a function of $\mathrm{UF}_{6}$ mass

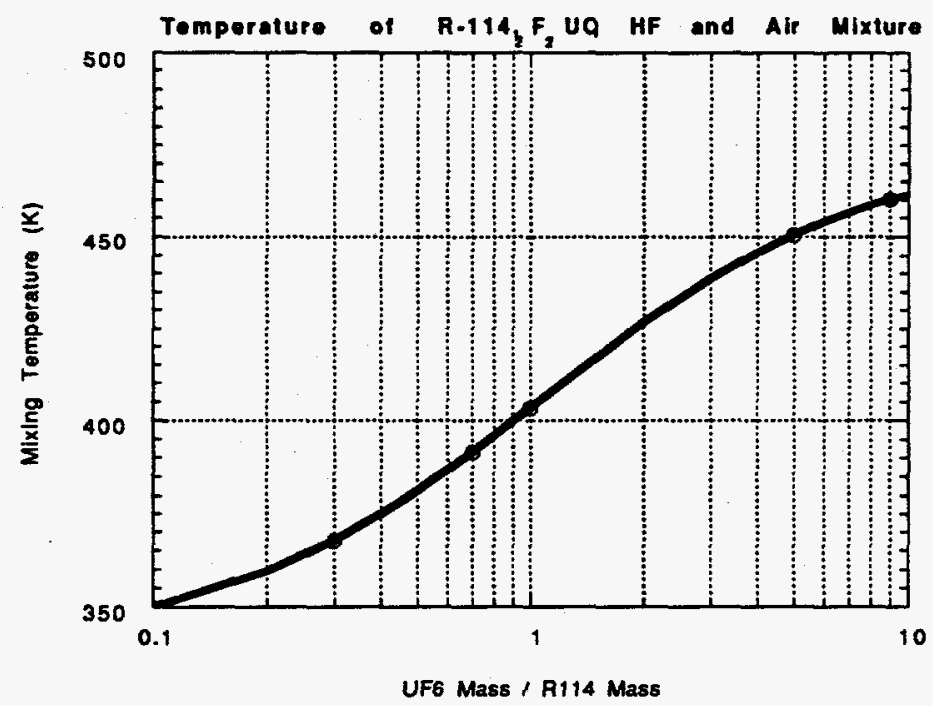

Figure 2 Temperature of $\mathrm{R}-114, \mathrm{UO}_{2} \mathrm{~F}_{2}, \mathrm{HF}$ and air mixture as a function of mass ratio of UF 6 to $R-114$ 


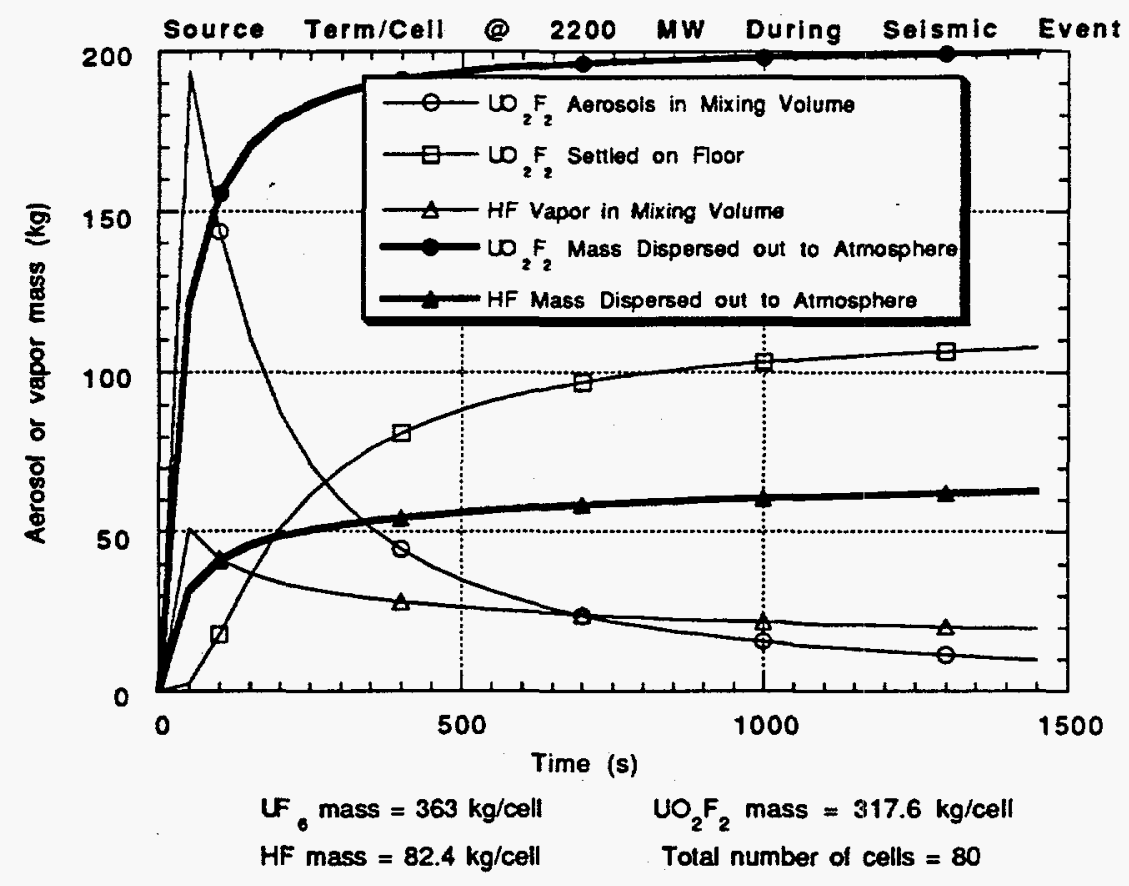

Figure $3 \mathrm{UO}_{2} \mathrm{~F}_{2}$ and $\mathrm{HF}$ mass variation for $2,200 \mathrm{MW}$ case

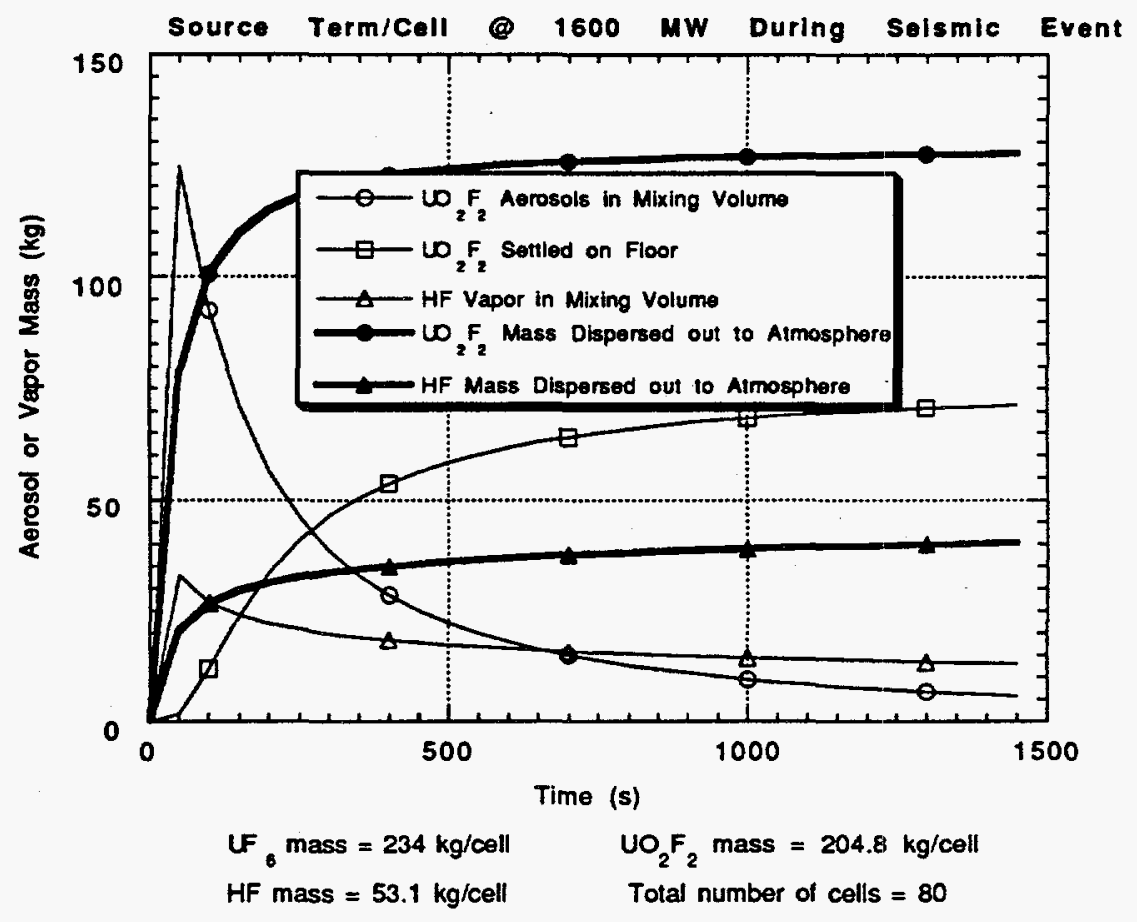

Figure $4 \mathrm{UO}_{2} \mathrm{~F}_{2}$ and $\mathrm{HF}$ mass variation for $1,600 \mathrm{MW}$ case 


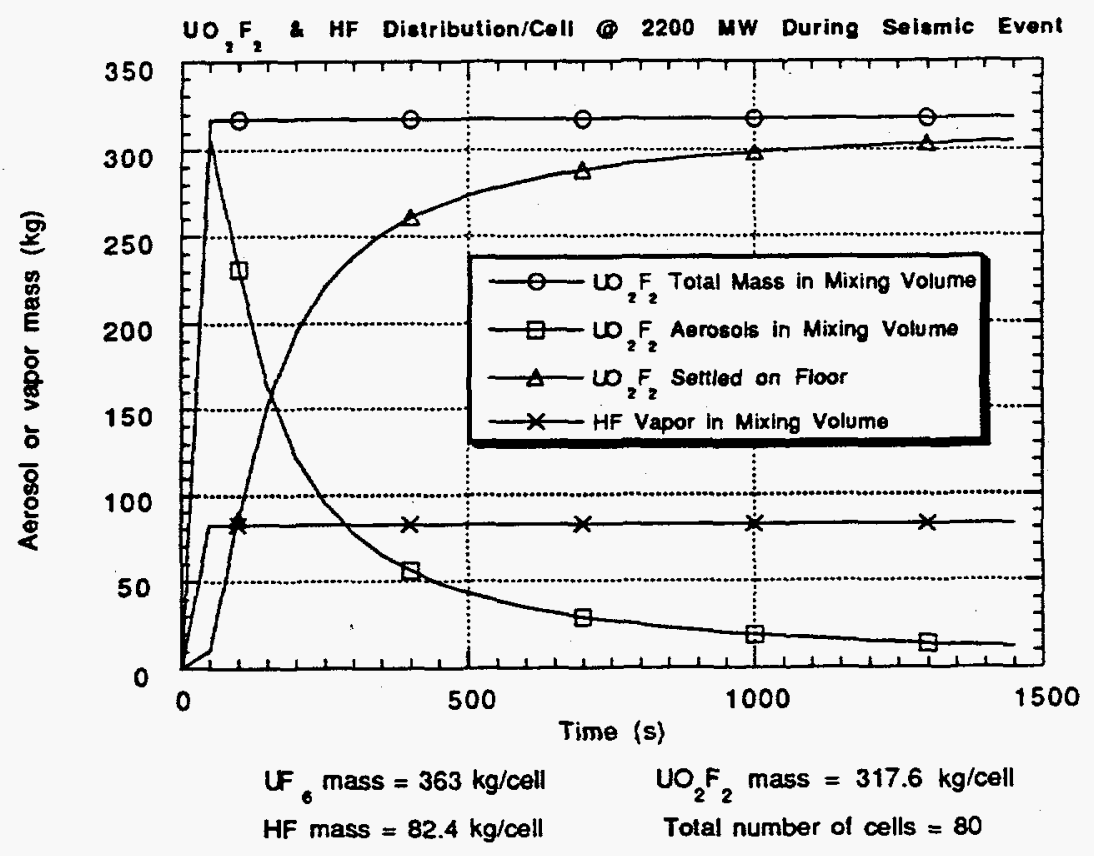

Figure $5 \mathrm{UO}_{2} \mathrm{~F}_{2}$ and $\mathrm{HF}$ mass variation within a closed volume for 2,200 MW case

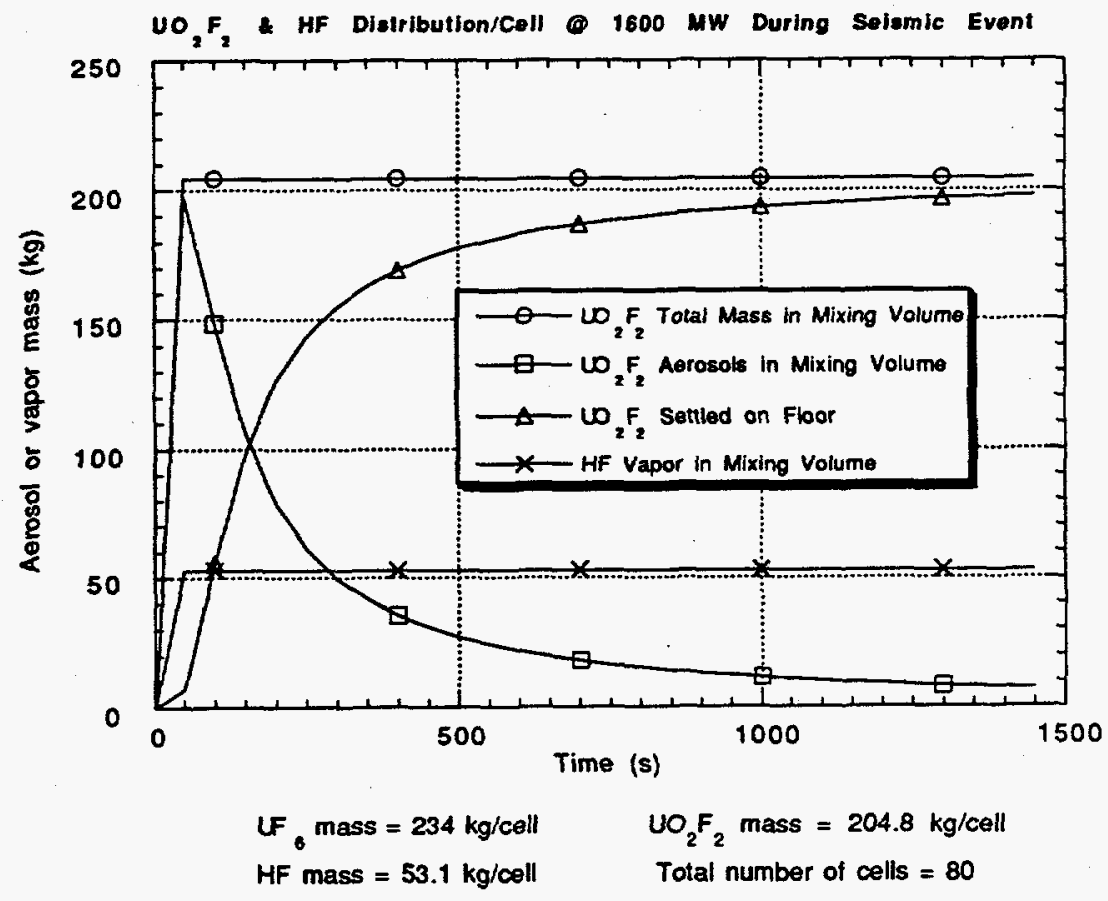

Figure $6 \mathrm{UO}_{2} \mathrm{~F}_{2}$ and $\mathrm{HF}$ mass variation within a closed volume for $1,600 \mathrm{MW}$ case 
Internal Distribution List

$\begin{array}{llll}\text { 1. } & \text { N.C.J. Chen } & 15-17 . & \text { R.P. Taleyarkhan } \\ 2 . & \text { W.G. Craddick } & 18 . & \text { D. A. Walker } \\ 3 . & \text { W.D. Goode } & 19 & \\ 4 . & \text { E.C. Fox } & 20 . & \text { ORNL Patent Section } \\ \text { 5-9. } & \text { K.D. Keith } & 21 . & \text { Central Research Library } \\ 10-12 . & \text { S.H. Kim } & 22-23 . & \text { K-25 Document Center } \\ 13 . & \text { D. A. Lombardi } & & \text { Deparatory Records } \\ 14 . & \text { R.W. Schmidt } & & \end{array}$

\section{External Distribution}

39. J.C. Carter, 600 Forest Heights Drive, Knoxville, Tennessee, 37919

40. Randall M. Devault, 55 Jefferson, Oak Ridge, Tennessee, 37831

41. R.H. Dyer, Dyer Enterprises, 301 Old Suddath Road, Harriman, Tennessee 37748

42. P. G. Ellison, Lockheed Martin Idaho Technologies, Idaho National Engineering, Laboratory, P.O. Box 1625, Idaho Falls, Idaho 83415-3850

43. R.T. Lahey, Jr. JEC, Rensselaer Polytechnic Institute, Troy, New York, 121803590

44-45. DOE, Office of Scientific and Technical Information, P.O. Box 62, Oak Ridge, Tennessee 37831 


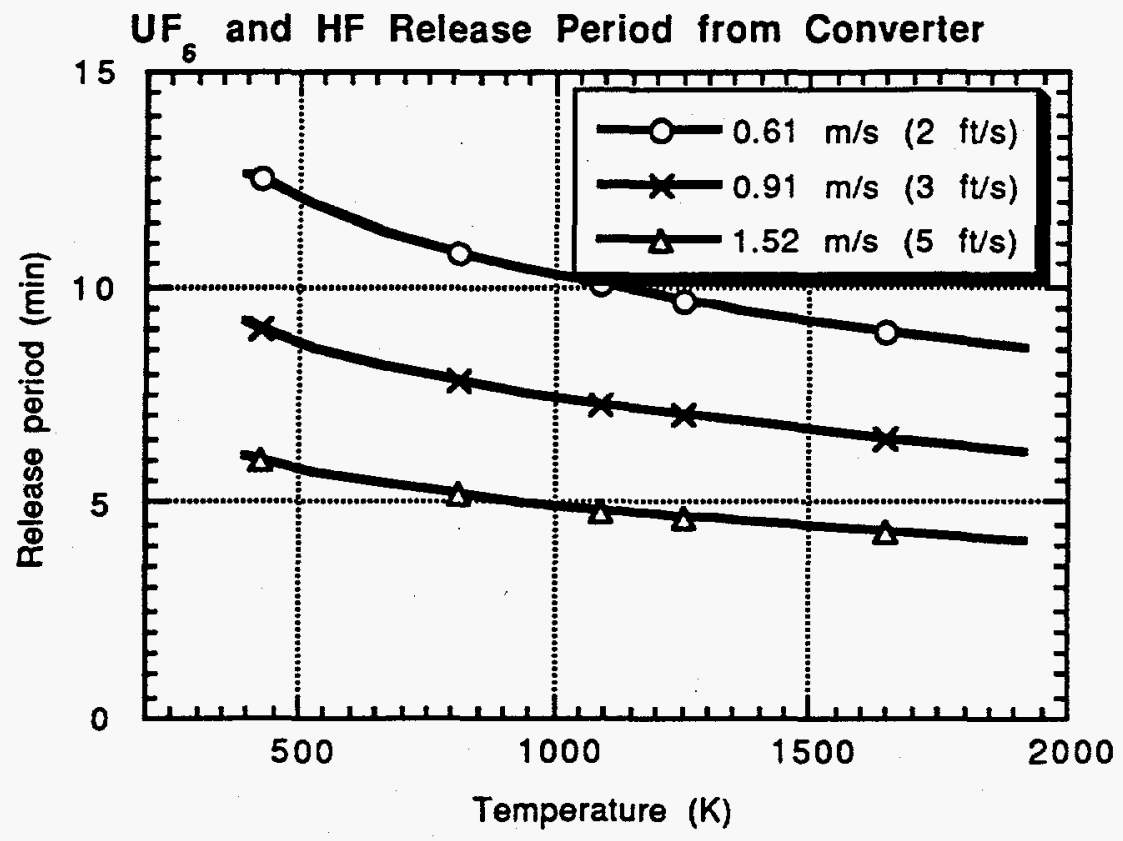

Figure $9 \mathrm{UF}_{6}$ and HF Release Period from Converters 
Internal Distribution List

$\begin{array}{llll}\text { 1. } & \text { N.C.J. Chen } & 15-17 . & \text { R.P. Taleyarkhan } \\ 2 . & \text { W.G. Craddick } & 18 . & \text { D. A. Walker } \\ \text { 3. } & \text { W.D. Goode } & & \\ 4 . & \text { E.C. Fox } & 19 & \text { ORNL Patent Section } \\ \text { 5-9. } & \text { K.D. Keith } & 20 . & \text { Central Research Library } \\ \text { 10-12. } & \text { S.H. Kim } & 21 . & \text { K-25 Document Center } \\ \text { 13. } & \text { D. A. Lombardi } & 22-23 . & \text { Laboratory Records } \\ 14 . & \text { R.W. Schmidt } & & \text { Department }\end{array}$

\section{External Distribution}

39. J.C. Carter, 600 Forest Heights Drive, Knoxville, Tennessee, 37919

40. Randall M. Devault, 55 Jefferson, Oak Ridge, Tennessee, 37831

41. R.H. Dyer, Dyer Enterprises, 301 Old Suddath Road, Harriman, Tennessee 37748

42. P. G. Ellison, Lockheed Martin Idaho Technologies, Idaho National Engineering, Laboratory, P.O. Box 1625, Idaho Falls, Idaho 83415-3850

43. R.T. Lahey, Jr. JEC, Rensselaer Polytechnic Institute, Troy, New York, 121803590

44-45. DOE, Office of Scientific and Technical Information, P.O. Box 62, Oak Ridge, Tennessee 37831 